\title{
Influence of solar radiation on nitrogen recovery by the biomass grown in high rate ponds
}

\author{
Eduardo de Aguiar do Couto*, Maria Lúcia Calijuri, Paula Peixoto Assemany, \\ Mariana Daniel Tango, Aníbal da Fonseca Santiago
}

Federal University of Viçosa (Universidade Federal de Viçosa/UFV), Departament of Civil Engineering, Environmental Engineering Group - nPA, Campus Viçosa, 36570-900 Viçosa, MG, Brazil

\section{A R T I C L E I N F O}

\section{Article history:}

Received 15 August 2014

Received in revised form 30 January 2015

Accepted 5 April 2015

Available online 11 April 2015

\section{Keywords:}

Nitrogen assimilation by biomass

Microalgae

High rate ponds

Microalgae/bacteria consortium

\begin{abstract}
A B S T R A C T
The objective of this study was to assess the effect of different solar radiation intensities on nitrogen assimilation by a consortium of bacteria and microalgae grown in pilot scale high rate ponds (HRP) treating domestic wastewater. The HRPs received effluent from an anaerobic reactor. The experiment was carried out under tropical climate conditions. A total of five HRPs were used; four of them were covered with shading screens that blocked $9 \%, 18 \%, 30 \%$ and $60 \%$ of the incident solar radiation. Nitrification was the main process for nitrogen removal/transformation in all HRPs and the volatilization of ammonia nitrogen occurred in levels below the expected range due to low $\mathrm{pH}$ values. The organic nitrogen concentration followed the same trend of the biomass production, but no statistical difference was found between the $60 \%$ screen HRP and the uncovered one, which led to the conclusion that the intensity of the photosynthetically active radiation does not compromise nitrogen assimilation, since the bacterial biomass may develop in conditions that are unfavorable to the growth of microalgae. Moreover, other aspects, such as $\mathrm{CO}_{2}$ addition, may reduce nitrogen losses by volatilization and denitrification, as well as contribute to recover this nutrient through biomass assimilation.
\end{abstract}

(c) 2015 Elsevier B.V. All rights reserved.

\section{Introduction}

Domestic wastewater discharge into water bodies without proper treatment is among the main sources of nitrogen release in the environment (Babu et al., 2011). Despite being an essential component of several biomolecules such as nucleotides and amino acids, its high availability in the inorganic forms of $\mathrm{N}^{-\mathrm{NH}_{4}}{ }^{+}$, $\mathrm{N}-\mathrm{NO}_{2}{ }^{-}$and $\mathrm{N}-\mathrm{NO}_{3}{ }^{-}$may result, among other consequences, in the intensification of the eutrophication process (Camargo and Alonso, 2006).

Aiming not only at the compliance with discharge standards, but also at the recovery and use of the nitrogen in human excreta, the use of microalgae for wastewater bioremediation has gained significant importance (Craggs et al., 2011; Rawat et al., 2011; Olguín, 2012; Arbib et al., 2013; Pires et al., 2013). Microalgae release oxygen through photosynthesis, which can significantly improve the aerobic degradation of the organic matter

\footnotetext{
* Corresponding author. Tel.: +55 31 38993098; fax: +55 3138993098 .

E-mail address: eduardo.acouto@hotmail.com (E. de Aguiar do Couto).
}

(Prajapati et al., 2013). On the other hand, heterotrophic bacteria release $\mathrm{CO}_{2}$, which contributes to microalgae growth. This consortium of microorganisms has been proven efficient in the depuration of wastewater (Subashchandrabose et al., 2011). Through microalgae growth systems, nitrogen is not only removed, but also recovered as biomass that can be used in several forms such as fertilizer, biofuel substrate, animal feedstock, pigment production, among others (Chisti, 2007; Avagyan, 2011; Silva et al., 2014; Krzemínska et al., 2014).

Within this context, the high rate ponds (HRPs) are one of the main alternatives for wastewater treatment and biomass production, despite some disadvantages such as the greater risk of contamination, evaporation losses, and especially the greater area requirement (Arbib et al., 2013; Peccia et al., 2013). Their main advantages are low installation costs and energy consumption, which reduces operating costs (de Godos et al., 2010; Pittman et al., 2011).

Environmental factors, such as light and temperature, play an important role in wastewater treatment efficiency and biomass production in HRPs. The light provides the energy required for the photosynthetic reactions that convert dissolved organic nutrients 
into organic molecules (Sutherland et al., 2014). However, according to Chisti (2007), high solar radiation levels may damage the microalgae photosynthetic machinery, and consequently their growth, which is known as photoinhibition. Krzemínska et al. (2014) state that in natural systems, changes in light quantity induce alterations in the biochemical composition of microalgae.

With respect to nitrogen removal/transformation processes, ammonia volatilization is favored given that the incidence of solar light and the microalgal photosynthetic activity increase the $\mathrm{pH}$ of the culture medium (Park and Craggs, 2011). In these conditions, we highlight the risk of microalgal growth inhibition if the free ammonia concentration reaches too high values $\left(>30 \mathrm{mg} \mathrm{L}^{-1}\right)$ in $\mathrm{pH}>9.0$ and temperature between $20^{\circ} \mathrm{C}$ and $25^{\circ} \mathrm{C}$ (Azov and Goldman, 1982). González-Fernández et al. (2011) state that high nitrogen removals do not always correspond to a high recovery of this nutrient, since losses due to $\mathrm{N}_{-} \mathrm{NH}_{4}{ }^{+}$volatilization and/or nitrification-denitrification are significant. Thus the advantages of biomass use are often overestimated.

Even though the HRPs represent a quite consolidated technology, there are several ways to optimize their operation toward increasing biomass production and nutrient removal (Sutherland et al., 2014). Therefore, the objective of this study was to assess the effect of different solar radiation intensities on the assimilation of nitrogen by biomass grown in pilot-scale high rate ponds. The study compared the results using ponds with the same dimensions and culture medium, submitted to different radiation intensities.

\section{Material and methods}

\subsection{Experimental unit}

The experiment was carried out at the Integrated Experimental Unit for Wastewater Treatment and Reuse, in the city of Viçosa, Minas Gerais, Brazil $\left(20^{\circ} 45^{\prime} 14^{\prime \prime} \mathrm{S}\right.$ and $\left.42^{\circ} 52^{\prime} 54^{\prime \prime} \mathrm{W}\right)$. Viçosa is located at approximately $648 \mathrm{~m}$ above sea level; the annual average precipitation is $1221 \mathrm{~mm}$ and the annual average temperature ranges between $19^{\circ} \mathrm{C}$ and $20^{\circ} \mathrm{C}$ The average relative humidity is $81 \%$. The local climate is characterized as tropical altitude, with hot and rainy summers, and cold and dry winters.

The studied treatment system consisted of a full-scale upflow anaerobic sludge blanket (UASB) reactor, and five pilot-scale high rate ponds (HRP). The UASB reactor received raw domestic sewage, after preliminary treatment. This reactor had a volume of $48 \mathrm{~m}^{3}$ and height of $5.7 \mathrm{~m}$, it was operated with an average effluent flow of $115 \mathrm{~m}^{3}$ day $^{-1}$ and a hydraulic retention time (HRT) of $7 \mathrm{~h}$. Bastos et al. (2010) operating the same UASB reactor in the same described conditions, related removals efficiencies of biochemical oxygen demand $\left(\mathrm{BOD}_{5}\right)$, chemical oxygen demand (COD) and total suspended solids (TSS) of $83 \%, 73 \%$ and $76 \%$, respectively.

The HRPs were made from fiberglass and had the following dimensions: width $=1.28 \mathrm{~m}$, length $=2.86 \mathrm{~m}$, total depth $=0.5 \mathrm{~m}$, useful depth $=0.3 \mathrm{~m}$, surface area $=3.3 \mathrm{~m}^{2}$, useful volume $=1 \mathrm{~m}^{3}$. The inlet flow was manually regulated to $10.4 \mathrm{Lh}^{-1}$ to maintain an HRT of 4 days. The paddlewheels were driven by a 1 hp electric motor. Rotation was reduced by a reduction gear coupled to the motor and controlled by a frequency inverter (WEG, series CFW-10) to provide a mean horizontal water velocity of approximately $0.10-0.15 \mathrm{~m} \mathrm{~s}^{-1}$. The HRPs were different with respect to screens that provided different shade levels. The first pond was the control unit without any cover (HRPcontrol). The other ponds had shading screens that blocked $9 \%, 18 \%, 30 \%$ and $60 \%$ of the solar radiation (HRP9\%, HRP $18 \%$, HRP30\% and HRP60\%). The screens are the same as those used for protected cultivation, manufactured in high density polyethylene (Equipesca ${ }^{\circledR}$, Sombrite ${ }^{\circledR}$, type 1000). Fig. 1 presents a scheme of the experimental treatment system.

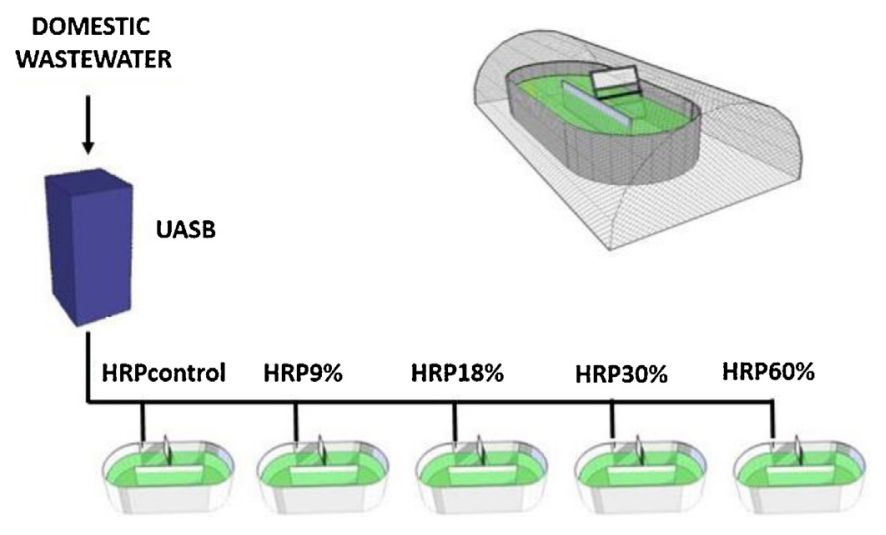

Fig. 1. Experiment scheme.

The five HRPs received effluent from the UASB reactor. No inoculum was added in the ponds, since the objectives were to verify the growth of autochthonous species in local conditions, and establish a consortium of microorganisms, in view of the possible benefits in terms of survival, biomass production and nutrient recovery (Bhatnagar et al., 2010; Renuka et al., 2013).

\subsection{High rate ponds operation and maintenance}

The five HRPs used in the experiment were monitored from January to November of 2012. Samples were collected at weekly intervals, totaling 32 samples. On sampling days, environmental variables such as $\mathrm{pH}$, dissolved oxygen (DO) temperature of the culture medium and photosynthetically active radiation (PAR) were measured at the site, every two hours, from 8 a.m. to 6 p.m. The variables $\mathrm{pH}$, dissolved oxygen (DO) and temperature were measured using the Hach HQ40d portable meter (Luminescent Dissolved Oxygen for DO). The PAR was measured using the LI-COR LI-193 Underwater Spherical Quantum Sensor.

Composite samples were collected for the analysis of the other physical and chemical variables: total Kjeldahl nitrogen (TKN) $\left(4500-\mathrm{N}_{\text {org }} \mathrm{C}\right)$, ammonia nitrogen $\left(4500-\mathrm{NH}_{3} \mathrm{C}\right)$, nitrate (4500- $\mathrm{NO}_{3} \mathrm{E}$ ), and volatile suspended solids (VSS) (2540E). The analyses were performed as recommended by the Standard Methods for the Examination of Water and Wastewater (APHA, 2005), and the methods used for analysis of each variable are between parentheses. The organic nitrogen $\left(\mathrm{N}_{\text {org }}\right)$ was calculated as the difference between TKN and $\mathrm{N}-\mathrm{NH}_{4}{ }^{+}$. The chlorophyll-a ( $\mathrm{chl} a$ ) levels were determined by spectrophotometry according to APHA (2005), and the calculations were performed using equations described in the NEN 6250 (1981).

The characterization of the phytoplankton community was performed at the genera level, with samples collected at a 2-week interval. For qualitative analysis, the samples were collected using a $20 \mu \mathrm{m}$ mesh-size plankton net and preserved with formalin solution (4\%). The proper identification of the genera present in the experimental units was carried out consulting identification keys, appropriate bibliography (Bourrely, 1970; Parra et al., 1982; Bicudo and Menezes, 2006) and specialists. For the quantitative analysis, $1 \mathrm{~L}$ effluent samples were collected and immediately preserved with Lugol's solution in amber bottles. The cells were counted using a Sedgwick-Rafter chamber under a binocular microscope (Olympus IX70). After sedimentation, the supernatant was discarded and the remaining concentrate of approximately $100 \mathrm{~mL}$ was homogenized and transferred using a pipette to the Sedgwick-Rafter chamber. After $15 \mathrm{~min}$, the chamber was taken to the microscope for counting with $400 \times$ magnification. 


\subsection{Mass balance}

The total nitrogen mass balance considered that the nitrogen load of the pond influent is equivalent to the effluent load, added to the nitrogen consumed in the denitrification, volatilization and sedimentation processes, as shown in the following equation:

$R_{\text {den }}=Q \times N_{\text {in }}-\left[Q \times N_{\text {out }}+\mathrm{Vol}+\mathrm{Sed}\right]$

where $R_{\mathrm{den}}$ is the denitrification rate in the ponds ( $\mathrm{g} \mathrm{day}^{-1}$ ), $N_{\text {in }}$ is the initial concentration of total nitrogen $\left(\mathrm{g} \mathrm{m}^{-3}\right), N_{\text {out }}$ is the final concentration of total nitrogen $\left(\mathrm{g} \mathrm{m}^{-3}\right)$, Vol is the volatilization rate $\left(\mathrm{g} \mathrm{day}^{-1}\right)$, Sed is the sedimentation rate $\left(\mathrm{g} \mathrm{day}^{-1}\right)$ and $Q$ is the flow in the HRPs $\left(\mathrm{m}^{3}\right.$ day $\left.^{-1}\right)$.

The ammonia volatilization was obtained from the percentage of free ammonia as a function of temperature and pH (Emerson et al., 1975):

$\frac{\text { FreeNH }_{3}}{\text { Totalammonianitrogen }}=\frac{100}{\left(1+10^{\{[0.09018+(2729.92 /(\mathrm{T}+273.20))]-\mathrm{pH}\}}\right)}$

Since the paddlewheels provide the constant mixing of the effluent in the ponds, which characterizes them as complete mix reactors, the sedimentation process was inexistent.

Two approaches may be used to determine the nitrogen fraction that has undergone denitrification: direct measurement or quantification of what has been volatilized, nitrified, assimilated by the biomass or not removed. This study adopted the latter.

\subsection{Statistical analysis}

The version 2.15 .2 of the statistical software $R^{\odot}$, developed by the R Foundation for Statistical Computing ( $R$ Development Core Team, 2013) was used to verify the differences among the results of the variables measured in the ponds.

\section{Results and discussion}

\subsection{Phytoplankton community}

The genera Chlorella sp. and Desmodesmus sp. were dominant in all ponds, during the entire sampling period. In the HRPcontrol, HRP9\%, HRP $18 \%$, HRP30\% and HRP60\%, the average abundances of Chlorella sp. were 37\%, 40\%, 37\%, 42\% and 52\%, and of Desmodesmus sp., these values were $35 \%, 38 \%, 45 \%, 44 \%$ and $37 \%$, respectively. The HRPcontrol presented abundance of Coelastrum sp. and Micractinium sp. in June (month with lower temperatures); then Chlorella sp. and Desmodesmus sp. became dominant again. Lower abundances of Scenedesmus sp., Chlorococcum sp. and Coelastrum sp. were observed throughout the monitoring period in the HRPcontrol, and Navicula sp. in the HRP9\% and HRP30\%, whereas the genera Ulothrix sp., Euglena sp. and Scenedesmus sp. were only observed in the HRP60\%. Fig. 2 presents the relative abundance of the main genera found in each HRP.

The aforementioned genera are commonly found in HRPs (Park and Craggs, 2010; Park et al., 2011a). Sutherland et al. (2014)

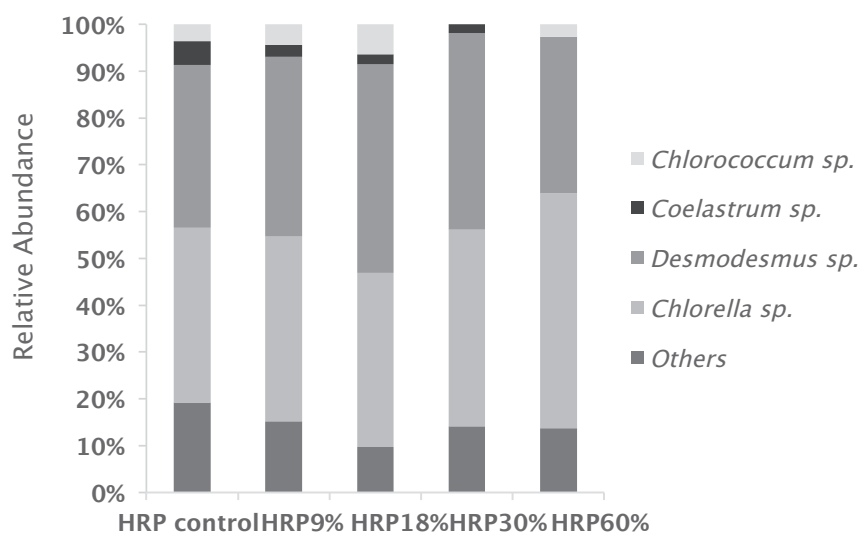

Fig. 2. Phytoplankton community within the HRPs.

also found the genus Chlamydomonas sp., not detected in this study. de Godos et al. (2009) found a greater diversity of genus in swine manure wastewater: Chlamydomonnas sp., Microspora sp., Chlorella sp., Nitzschia sp., Achananthes sp., Protoderma sp., Senelastrum sp., Oocystis sp., Ankistrodesmus sp., and Chlorella sp., this last one being the only genus also found in our study, despite the different type effluent and geographic location. The genera Desmodesmus sp., Coelastrum sp. and Micractinium sp. are colonial organisms with diameters usually greater than $200 \mu \mathrm{m}$, which favors sedimentation (Park et al., 2011b). This fact deserves special attention in the context of nutrient recovery, since the separation process is one of the main challenges of biomass use and may represent between 20 and 30\% of its costs (Mata et al., 2010). The occurrence of organisms of different sizes in the same sample may be due to the reduced size of the HRPs and their mixing frequency. In full-scale HRPs, the laminar flow regime may represent a problem and favor the stratification of organisms in the water column according to their size or weight (Sutherland et al., 2014).

\subsection{Environmental variables}

Table 1 shows the results (mean and standard deviation) obtained for the variables $\mathrm{pH}$, temperature, DO and PAR.

All ponds presented DO saturation during the day and lower values at night (data not shown). Park and Craggs (2011), when operating HRPs treating effluent from an anaerobic reactor, with retention times of 4 and 8 days and $\mathrm{CO}_{2}$ addition, obtained $\mathrm{DO}$ values similar to those presented in this study. The DO concentration in the UASB reactor effluent was due to the transport in turbulent regime to the reservoir where the sampling was carried out. The mean $\mathrm{pH}$ measured in the HRPs did not present statistical difference $(p<0.05)$, and the values did not exceed 8.5. The temperature in the ponds was proportional to the incident solar radiation at the surface, thus their values were influenced by the use of shading screens.

Table 1

$\mathrm{pH}, \mathrm{DO}$, temperature and PAR in the HRPs and in the effluent from the UASB reactor (mean and standard deviation).

\begin{tabular}{|c|c|c|c|c|c|c|}
\hline & UASB & HRPcontrol & HRP9\% & HRP18\% & HRP30\% & HRP60\% \\
\hline $\mathrm{pH}$ & $7.1(0.34)$ & $7.7(0.72)$ & $7.8(0.87)$ & $7.8(0.88)$ & $7.9(0.97)$ & $7.2(0.99)$ \\
\hline $\mathrm{DO}\left(\mathrm{mg} \mathrm{L}^{-1}\right)$ & $1.9(0.8)$ & $6.4(2.0)$ & $7.0(2.4)$ & $8.0(2.3)$ & $7.4(2.8)$ & $6.3(2.3)$ \\
\hline Temperature $\left({ }^{\circ} \mathrm{C}\right)$ & $23.9(1.8)$ & $24.3(2.3)$ & $23.9(2.3)$ & $23.7(2.3)$ & $23.6(2.2)$ & $22.8(2.2)$ \\
\hline 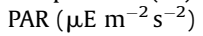 & - & $1087.3(697.6)$ & $871.5(577.4)$ & $815.4(513.4)$ & 707.3 (429) & $387.1(241.4)$ \\
\hline
\end{tabular}




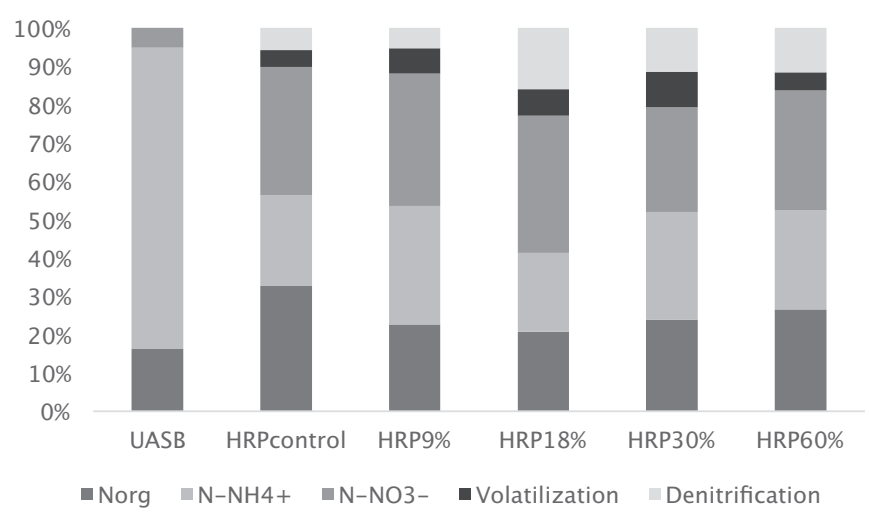

Fig. 3. Percentages of nitrogen forms in the HRPs and UASB reactor.

\subsection{Nitrogen removal and recovery}

Fig. 3 shows the mass balance for total nitrogen, in percentages. Table 2 shows the nitrogen loads and forms of removal in the HRPs. The total nitrogen concentration influent to the HRPs was $50.4 \mathrm{mg} \mathrm{L}^{-1}$, of which $78.4 \%$ was $\mathrm{N}-\mathrm{NH}_{4}{ }^{+}, 5.2 \%$ was $\mathrm{N}^{-\mathrm{NO}_{3}}{ }^{-}$and $16.4 \%$ was organic nitrogen. In all HRPs we observed a reduction in the ${\mathrm{N}-\mathrm{NH}_{4}}^{+}$loads, although not completely removed/transformed, and an increase in nitrate and organic nitrogen loads.

The $\mathrm{pH}$ values did not favor volatilization. The mean $\mathrm{pH}$ did not exceed 8.5 at any time of the monitoring period. The free ammonia percentage ranged from $5.5 \%$ in the $\mathrm{HRP} 60 \%$ to $12.5 \%$ in the HRP30\%. Park and Craggs (2011) and de Godos et al. (2010) obtained different results, with higher percentages of volatilization. Heubeck et al. (2007) state that the greater the carbon demand of the microalgae culture medium, the higher the elevation of $\mathrm{pH}$ with the photosynthetic activity, which consequently increases ammonia volatilization. The C:N:P mass ratio of the anaerobic effluent used as culture medium in this experiment was 22:12:1, which corresponds to a carbon-limited environment if compared to the 48:8:1 ratio required for rapid microalgal growth, according to Oswald (1960). However, under the conditions of this study, the limitation of the culture medium in terms of carbon did not reflect on higher percentages of free ammonia volatilization.

Any of the ponds was able to completely remove the applied ammonia nitrogen load, and the HRP18\% was the one with better performance. However, the effluent loads did not statistically differ $(p<0.05)$, which indicates no significant effect of solar radiation.

The HRPs affluent presented $45.3 \mathrm{mg} \mathrm{L}^{-1}$ of $\mathrm{N}^{-\mathrm{NH}_{4}}{ }^{+}$and the ammonia nitrogen in the HRPs effluent were $26.9 \mathrm{mg} \mathrm{L}^{-1}, 27.1 \mathrm{mg}$ $\mathrm{L}^{-1}, 20.4 \mathrm{mg} \mathrm{L}^{-1}, 26.3 \mathrm{mg} \mathrm{L}^{-1}$ and $26.3 \mathrm{mg} \mathrm{L}^{-1}$, in the HRPcontrol, HRP9\%, HRP18\%, HRP30\% and HRP60\%, respectively. None of the HRPs reached the limit established by Brazilian legislation for $\mathrm{N}-\mathrm{NH}_{4}{ }^{+}$discharge, which is $20 \mathrm{mg} \mathrm{L}^{-1}$.

Considering the aspect of effluent treatment aimed at meeting standard discharge limits, as well as the nutrient recovery by

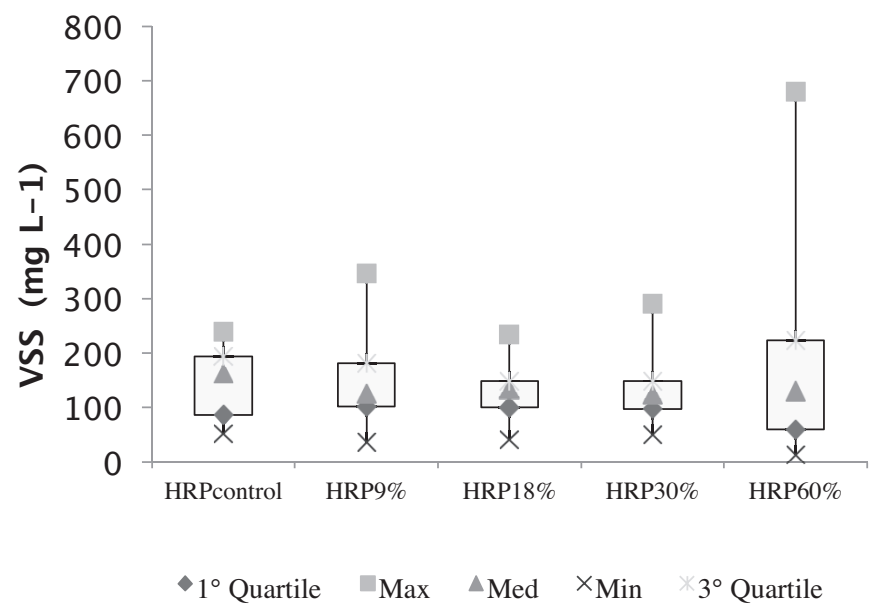

Fig. 4. VSS concentrations.

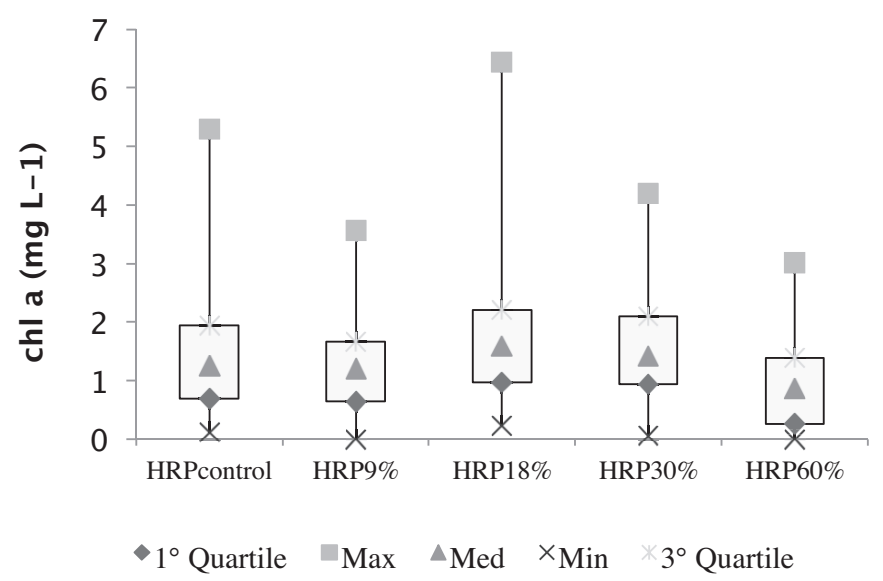

Fig. 5. chl a concentrations.

biomass assimilation, better results may be obtained with the increase of the retention time. Moreover, $\mathrm{CO}_{2}$ addition may favor algal growth, since it would supply the required inorganic carbon (Craggs et al., 2011; Sutherland et al., 2014).

In all treatments the $\mathrm{N}^{-\mathrm{NO}_{3}}{ }^{-}$concentration significantly increased, which represents the main form of transformation of the nitrogen influent to the HRPs. Ammonia nitrification is a common process in environments with high DO levels, as those observed in the present study. The mean $\mathrm{N}-\mathrm{NO}_{3}{ }^{-}$concentration ranged between $14 \mathrm{mg} \mathrm{L}^{-1}$ in the HRP18\% and $18 \mathrm{mg} \mathrm{L}^{-1}$ in the HRP30\%. Nitrate may represent an important nitrogen source for microalgal growth, despite their preference for ammonia nitrogen (Cai et al., 2013). González-Fernández et al. (2011) also found that nitrification was the main process of $\mathrm{N}^{-\mathrm{NH}_{4}}{ }^{+}$transformation in

Table 2

Mass balance for the nitrogen in the HRPs.

\begin{tabular}{|c|c|c|c|c|c|c|}
\hline Forms of $\mathrm{N}$ and removal routes $\left(\mathrm{g} \mathrm{day}^{-1}\right)$ & UASB & HRPcontrol & HRP9\% & HRP18\% & HRP30\% & HRP60\% \\
\hline $\mathrm{N}_{\text {org }}$ & 2.1 & 4.1 & 2.9 & 2.6 & 3 & 3.4 \\
\hline $\mathrm{N}-\mathrm{NH}_{4}{ }^{+}$ & 9.9 & 3 & 3.9 & 2.6 & 3.6 & 3.3 \\
\hline $\mathrm{N}-\mathrm{NO}_{3}-$ & 0.7 & 4.2 & 4.3 & 4.5 & 3.5 & 3.9 \\
\hline Volatilization & 0 & 0.6 & 0.8 & 0.9 & 1.2 & 0.6 \\
\hline Denitrification & 0 & 0.7 & 0.7 & 2 & 1.4 & 1.5 \\
\hline
\end{tabular}


Table 3

VSS and chla productivities and the VSS:chla ratio.

\begin{tabular}{|c|c|c|c|c|c|}
\hline & HRP control & HRP9\% & HRP18\% & HRP30\% & HRP60\% \\
\hline VSS productivity $\left(\mathrm{mg} \mathrm{m}^{-2} \mathrm{~d}^{-1}\right)$ & $11385(4470)$ & $10675(4625)$ & $9508(3071)$ & $10301(4486)$ & $11913(9845)$ \\
\hline Chla productivity $\left(\mathrm{mg} \mathrm{m}^{-2} \mathrm{~d}^{-1}\right)$ & $115(92)$ & $99(66)$ & $138(102)$ & $119(76)$ & $74(63)$ \\
\hline VSS:chla ratio & 98 & 112 & 69 & 88 & 163 \\
\hline
\end{tabular}

microalgal production using anaerobic effluent. The authors attributed that to the fact that the organic matter in the anaerobic effluent is not easily biodegradable, thus the DO was used in nitrification rather than in the oxidation of organic matter. Other studies show distinct results. Park and Craggs (2011) used anaerobically pre-treated domestic effluent and de Godos et al. (2010) used swine manure effluent after a primary decanter, and both did not detect the occurrence of nitrification. These authors, however, used longer retention times ( 8 and 10 days), which can also favor nitrate assimilation by the microalgae. Therefore, we must highlight that it is not possible to attribute nitrification only to the characteristics of the culture medium, since operation conditions may interfere in the process.

A small fraction of the total nitrogen influent to the HRPs was attributed to denitrification: $6 \%, 5 \%, 16 \%, 11 \%$ and $12 \%$, for HRPcontrol, HRP9\%, HRP18\%, HRP30\% e HRP60\%, respectively. The activity of denitrifying microorganisms requires low DO levels in the medium, which was obtained at night in the present study, as also reported by Park and Craggs (2011). Moreover, biomass can form flocks with an anoxic region inside. Thus denitrification occurs within these microenvironments (Toet et al., 2003). González-Fernández et al. (2011) state that cultivating biomass in microorganisms consortia contributes to the occurrence of denitrification due to the conditions that favor heterotrophic bacteria over microalgae, and as an example, the authors mention the increase in the organic load of the influent to the HRPs. In the present study, the influent organic load was the same for all HRPs, and the condition that could favor the growth of heterotrophic bacteria over microalgae would be the greater interception of the PAR. However, this effect was not observed, i.e., the HRP60\% did not present the highest denitrification percentage.

The mean organic nitrogen concentrations were $16.4 \mathrm{mg} \mathrm{L}^{-1}$, $11.6 \mathrm{mg} \mathrm{L}^{-1}, \quad 10.4 \mathrm{mg} \mathrm{L}^{-1}, \quad 12.0 \mathrm{mg} \mathrm{L}^{-1}$ and $13.6 \mathrm{mg} \mathrm{L}^{-1}$ in the HRPcontrol, HRP9\%, HRP18\%, HRP30\% and HRP60\%, respectively. The HRPcontrol was considered statistically different from the HRPs $9 \%, 18 \%$ and 30\% $(p<0.05)$. The organic nitrogen found in the HRP effluent regards that which is constituent of biomass cells. Compared with the HRP influent, the final mean concentrations increased 99\%, 38\%, 26\%, 45\% and 62\% in the HRPcontrol, HRP9\%, HRP $18 \%$, HRP30\% and HRP60\%, respectively. It is important to highlight that nitrogen recovery by biomass assimilation was higher than these values. The reason is the fact that the organic nitrogen concentration in the anaerobic effluent that fed the HRPs was part of the organic compounds not yet degraded. With the action of heterotrophic bacteria in the HRPs, these compounds were degraded and the nitrogen was made available for assimilation by the growing biomass.

Figs. 4 and 5 show the VSS and chlorophyll $a$ concentrations, and Table 3 shows the ratio between mean VSS values and chl $a$, as well as their productivities.

The VSS productivity was greater in the HRPcontrol and HRP60\%, however, with no statistical difference, at the 5\% significance level, if compared to the other HRPs, which allows us to state that in the present study, there was no observed effect of solar radiation on biomass production. As expected, even though there was no statistical difference among most of the means, the organic nitrogen followed the same tendency presented by the biomass production, i.e., the greater the biomass production, the greater the $\mathrm{N}_{\text {org }}$ production.

As for chlorophyll $a$, the HRP18\% presented higher concentrations than the HRP9\% and HRP60\%, and HRP 60\% presented lower concentrations than the HRP18\% and HRP30\% (with statistical significance $-p<0.05$ ), i.e., it was possible to observe the effect of solar radiation on the chl $a$ concentrations in the HRP18\% and HRP30\%. Some studies mention that high doses of radiation may cause the photoinhibition effect and damage microalgal growth (el Hamouri et al., 1994; Molina Grima et al., 2000; Chisti, 2007). However, our results do not allow us to affirm the occurrence of such phenomenon in the present study. In the HRPcontrol, the VSS concentration may have attenuated the radiation.

The higher proportion of non-algal biomass was obtained in the HRP60\% (>SSV/chl a), which received the lowest radiation intensity. The incident radiation on the HRP60\% compromised the microalgal growth, as shown by the chlorophyll $a$ values, but did not impact the nutrient recovery, since the organic nitrogen values in this pond did not statistically differ $(p<0.05)$ from those in the HRPcontrol.

Other studies that approached the nitrogen dynamics in microalgae cultivation were carried out under different situations with respect to the configuration of reactors, operating conditions, use of inoculums, type of substrate and environmental conditions, which justifies the amplitude of results reported in the literature (Park and Craggs, 2011; Ruiz-Martinez et al., 2012; Renuka et al., 2013; Samori et al., 2013). Added to that, the complex relationship among the microorganisms in the consortium needs a better understanding in order to optimize operational aspects of the HRPs and improve the purification of effluents (Subashchandrabose et al., 2011). In the present study, we observed that the radiation may affect the biomass composition, but does not compromise nitrogen recovery. However, the control of the required conditions and the adoption of other measures, such as $\mathrm{CO}_{2}$ addition, may contribute to that objective.

\section{Conclusion}

In this study, nitrification and biomass assimilation were the main routes for nitrogen removal/transformation in the HRPs. Nitrogen losses by volatilization of free ammonia and denitrification were small and did not vary with changes in the incident radiation.

It was possible to conclude that, under the conditions assessed in this study, the intensity of the PAR does not compromise nitrogen assimilation, since the bacterial biomass may develop in conditions that are unfavorable to microalgal growth. However, the relationships in the consortium of microorganisms in the HRPs need to be better evaluated and understood. Also, we verified that the different radiation levels had an effect on the effluent concentration of chlorophyll $a$, which is related to the composition of the biomass produced.

\section{Acknowledgements}

The authors acknowledge the financial assistance provided by the Minas Gerais State Secretariat for Science, Technology and 
Higher Education - SECTES, the Research Support Foundation of Minas Gerais - FAPEMIG and National Council for Scientific and Technological Development, CNPq.

\section{References}

American Public Health Association (APHA), 2005. Standard Methods for Examination of Water and Wastewater. American Water Work Association, Water Environmental Federation, Washington.

Arbib, Z., Ruiz, J., Álvarez-Dias, P., Garrido-Pérez, C., Barragan, J., Perales, J.A., 2013. Long term outdoor operation of a tubular air lift pilot photobioreactor and a high rate algal pond as tertiary treatment of urban wastewater. Ecol. Eng. 52, $143-153$.

Avagyan, A.B., 2011. Water global recourse management through the use of microalgae addressed to sustainable development. Clean Technol. Environ. Policy 13, 431-445.

Azov, Y., Goldman, S., 1982. Operation of high-rate oxidation ponds: theory and experiments. Water Res. 16, 1153-1160.

Babu, M.A., Van Der Steen, N.P., Hooijmans, C.M., Gijzen, H.J., 2011. Nitrogen mass balances for pilot-scale biofilm stabilization ponds under tropical conditions. Biores. Technol. 102, 3754-3760.

Bastos, R.K.X., Calijuri, M.L., Bevilacqua, P.D., Rios, E.N., Dias, E.H.O., Capelete, B.C., Magalhães, T.B., 2010. Post-treatment of UASB reactor effluent in waste stabilization ponds and in horizontal flow constructed wetlands: a comparative study in pilot scale in Southeast Brazil. Water Sci. Technol. 61, 995-1002.

Bhatnagar, A., Bhatnagar, M., Chinnasamy, S., Das, K.C., 2010. Chlorella minutissimaa promising fuel alga for cultivation in municipal wastewater. Appl. Biochem. Biotechnol. 161, 523-536.

Bicudo, C.E.M., Menezes, M., 2006. Gêneros de algas de águas continentais do Brasil (chave para identificação e descrições), 2a edição RiMa, São Carlos (in Portuguese)

Bourrely, P., 1970. Les algues d'eau douce. Initiation à la sistematique. III Les algues bleus et rouges. Les Eugléniens, Peridiniens et Cryptomonadines. Nouvelle Boubeé \& Cie, Paris, pp. 572p (in French).

Cai, T., Park, S.Y., Li, Y., 2013. Nutrient recovery from wastewater streams by microalgae: status and prospects. Renew. Sustain. Energy Rev. 19, 360-369.

Camargo, J.A., Alonso, A., 2006. Ecological and toxicological effects of inorganic nitrogen pollution in aquatic ecosystems: a global assessment. Environ. Int. 32 831-849.

Chisti, Y., 2007. Biodiesel from microalgae. Biotechnol. Adv. 25, 294-306.

Craggs, R.J., Heubeck, S., Lundquist, T.J., Benemann, J.R., 2011. Algal biofuels from wastewater treatment high rate algal ponds. Water Sci. Technol. 63 (4), 660-665.

de Godos, I., Blanco, S., García-Encina, P.A., Becares, E., Muñoz, R., 2010. Influence of flue gas sparging on the performance of high rate algae ponds treating agroindustrial wastewaters. J. Hazard. Mater. 179, 1049-1054.

el Hamouri, B., Khallayoune, K., Bouzoubaa, N., Chalabi, M., 1994. High-rate algal pond performances in faecal coliforms and helminth egg removals. Water Sci. Technol. 28 (1), 171-174.

Emerson, K. Russo, R.E., Lund, R.E., Thurston, R.V., 1975. Aqueous ammonia equilibrium calculations: effect of $\mathrm{pH}$ and temperature. J. Fish. Res. Board Can. 32 (12), 2379-2383.

González-Fernández, C., Molinuevo-Salcez, B., Gaecía-González, M., 2011. Nitrogen transformations under different conditions in open ponds by means of microalgae-bacteria consortium treating pig slurry. Biores. Technol. 102, 960-966.

Heubeck, S., Craggs, R.J., Shilton, A., 2007. Influence of $\mathrm{CO}_{2}$ scrubbingfrom biogas on the treatment performance of a high rate algal pond. Water Sci. Technol. 55 (11), 193-200.

Krzemínska, I., Skowronska, B.P., Trzcinska, M., Tys, J., 2014. Influence of photoperiods on the growth rate and biomass productivity of green microalgae. Bioprocess Biosyst. Eng. 37, 735-741.
Mata, T.M., Martins, A.A., Caetano, N.S., 2010. Microalgae for biodiesel production and other applications: a review. Renew. Sustainable Energy Rev. 14, 217-232. Molina Grima, E., Acién Fernández, F.G., Camacho, F.G., Rubio, F.C., Chisti, Y., 2000. Scale-up of tubular photobioreactors. J. Appl. Phycol. 12, 355-368.

Nederlands Norm (NEN). NEN 6520, 1981, 1981. Water: spectrophotometric determination of chlorophyll a content. Delft. Nederlands NormalisatieInstituut, The Netherlands (In Dutch).

Olguín, E.J., 2012. Dual purpose microalgae-bacteria-based systems that treat wastewater and produce biodiesel and chemical products within a Biorefinery. Biotechnol. Adv. 30, 1031-1046.

Oswald, W.J., 1960. Fundamental factors in stabilization pond design. Proceedings of 3rd Conference on Biological Waste Treatment. Manhattan College, New York.

Park, J.B.K., Craggs, R.J., 2010. Wastewater treatment and algal production in high rate algal ponds with carbon dioxide addition. Water Sci. Technol. 61 (3), 633-639.

Park, J.B.K., Craggs, R.J., 2011. Nutrient removal in wastewater treatment high rate algal ponds with carbon dioxide addition. Water Sci. Technol. 63 (8), 1758-1764.

Park, J.B.K., Craggs, R.J., Shilton, A.N., 2011a. Wastewater treatment high rate algal ponds for biofuel production. Biores. Tecnol. 102, 35-42.

Park, J.B.K., Craggs, R.J., Shilton, A.N., 2011b. Recycling algae to improve species control and harvest efficiency from a high rate algal pond. Water Res. 45, 6637-6649.

Parra, O.O., Gonzalez, M., Dellarossa, V., Rivera, P., Orellana, M., 1982. Manual taxonômico del fitoplancton de águas continentales. V-Chlorophyceae Concepcion (in Spanish).

Peccia, J., Haznedaroglu, B., Gutierrez, J., Zimmerman, J.B., 2013. Nitrogen supply is an important driver of sustainable microalgae biofuel production. Trends Biotechnol. 31, 134-138.

Pires, J.C.M., Alvim-Ferraz, M.C.M., Martins, F.G., Simões, M., 2013. Wastewater treatment to enhance the economic viability of microalgae culture. Environ. Sci. Pollut. Res. 20 (8), 5096-5105.

Pittman, J.K., Dean, A.P., Osundeko, O., 2011. The Potential of Sustainable algal biofuel production using wastewater resources. Biores. Technol. 102, 17-25.

Prajapati, S.K., Kaushik, P., Malik, A., Vijay, V.K., 2013. Phycoremediation coupled production of algal biomass, harvesting and anaerobic digestion: possibilities and challenges. Biotechnol. Adv. 31, 1408-1425.

R Development Core Team, 2013. A Language and Environment for Statistical Computing. R Foundation for Statistical Computing, Vienna, Austria [cited Jan 15] Available from 2013; http://www.R-project.org.

Rawat, I., Kumar, R.R., Mutanda, T., Bux, F., 2011. Dual role of microalgae: phycoremediation of domestic wastewater and biomass production for sustainable biofuels production. Appl. Energy 88, 3411-3424.

Renuka, N., Sood, A., Ratha, S.K., Prassanna, R., Ahluwalia, A.S., 2013. Evaluation of microalgal consortia for treatment of primary treated sewage effluent and biomass production. J. Appl. Phycol. 25, 1529-1537.

Ruiz-Martinez, A., Martin Garcia, N., Romero, I., Seco, A., Ferrer, J., 2012. Microalgae cultivation in wastewater: nutrient removal from anaerobic membrane bioreactor effluent. Biores. Technol. 126, 247-253.

Samori, G., Samori, C., Guerrini, F., Pistocchi, R., 2013. Growth and nitrogen remova capacity of Desmodesmus communis and of a natural microalgae consortium in a batch culture system in view of urban waste water treatment: part I. Water Res. 47, 791-801.

Silva, T.L., Gouveia, L., Reis, A, 2014. Integrated microbial processes for biofuels and high value-added products: the way to improve the cost effectiveness of biofuel production. Appl. Microbiol. Biotechnol. 98, 1043-1053.

Subashchandrabose, S.R., Ramakrishnan, B., Megharaj, M., Venkateswarlu, K., Naidu, R., 2011. Consortia of cyanobacteria/microalgae and bacteria: biotechnological potential. Biotechnol. Adv. 29, 896-907.

Sutherland, D.L., Turnbull, M.H., Craggs, R.J., 2014. Increased pond depth improves algal productivity and nutrient removal in wastewater treatment high rate algal ponds. Water Res. 53, 271-281.

Toet, A., Huiber, L.H.F.A., Van Logtestijin, R.S.P., Verhoeven, J.T.A., 2003. Denitrification in the periphyton associated with plant shoots and in the sediment of a wetlands system supplied with sewage treatment plant effluent. Hydrobiologia 501, 29-44. 